\title{
Phenology of tropical understory trees: patterns and correlates
}

\author{
W. Alice Boyle ${ }^{1} \&$ Judith L. Bronstein ${ }^{2}$ \\ 1. Centre for Applied Conservation Biology, Department of Forest Sciences, 3004-2424 Main Mall, University of British \\ Columbia, Vancouver, BC, Canada, V6T 1Z4; aboyle7@uwo.ca \\ 2. Department of Ecology and Evolutionary Biology, Biological Sciences West Bldg., room 310, 1041 E Lowell St., \\ University of Arizona, Tucson, AZ, 85721-0088, USA; judieb@email.arizona.edu
}

\author{
Received 29-VIII-2011. C Corrected 20-III-2012. Accepted 19-IV-2012.
}

\begin{abstract}
Reproductive phenologies of plants are constrained by climate in highly seasonal regions. In contrast, plants growing in wet tropical forests are freed from many abiotic constraints, which in canopy tree communities lead to a rich diversity of phenological patterns within and among individuals, species and communities. However, basic descriptions of tropical phenological patterns and the processes that shape them are rare. Here, we document the individual-, population-, and landscape-level phenological patterns of two dominant families of understory woody plants important to avian frugivores, the Melastomataceae and Rubiaceae, along an elevational transect in Costa Rica. The 226 individual plants belonging to 35 species in this study, varied in the number of reproductive bouts/year, and the timing, duration, and synchrony of reproductive stages. This variation was not related to factors related to their interactions with mutualists and antagonists, nor did it appear to be constrained by phylogeny. Diverse phenological patterns among species led to relatively aseasonal patterns at the community and landscape level. Overall, evidence for biotic processes shaping temporal patterns of fruiting phenology was weak or absent. These findings reveal a number of unexplained patterns, and suggest that factors shaping phenology in relatively aseasonal forests operate in idiosyncratic ways at the species level. Rev. Biol. Trop. 60 (4): 1415-1430. Epub 2012 December 01.
\end{abstract}

Key words: climate, Costa Rica, frugivory, fruit pathogens, phenological patterns, seed dispersal mutualisms, tropical wet forest.

Interest in phenological patterns and the processes controlling them has increased dramatically in recent years, in part due to growing interest in how changing climate affects the timing of life cycles of plants (Corlett \& LaFrankie 1998, Price \& Waser 1998, Gordo \& Sanz 2005) and animals (Cotton 2003, MacMynowski \& Root 2007). Recent phenological studies have primarily focused on temperate communities, in which phenologies are constrained by seasonality of temperature and moisture regimes (Ting et al. 2008). In contrast, conditions remain conducive to growth and reproduction over the entire year in wet tropical regions. For this reason, phenological patterns of tropical organisms are more diverse and are influenced by a broader set of selective pressures than those of temperatedwelling organisms.

Most plants of temperate (Rathcke \& Lacey 1985, Lechowicz 1995) and seasonally dry tropical regions (McLaren \& McDonald 2005, Mduma et al. 2007) complete only a single, relatively synchronous reproductive cycle each year. In less seasonal tropical regions, plants exhibit a wide variety of phenologies (Bawa 1983, Newstrom et al. 1994, Reich 1995, Singh \& Kushwaha 2006), reproducing on supra-annual (Sakai 2002) to sub-annual (Galetto et al. 2000) cycles. Tropical species also differ in the degree of within- and amongindividual synchrony, from extreme synchrony (Augspurger 1983) to high asynchrony (Bronstein \& Patel 1992). 
Our primary goal was to characterize reproductive phenologies (temporal patterns of both flowering and fruiting) of a group of understory plants most prevalent in diets of understory tropical frugivorous birds. Community-level surveys of plant phenology in the wet tropics have mainly focused on canopy trees (Newstrom et al. 1991, Bhat 1992, Berlin et al. 2000, Sakai 2002, Anderson et al. 2005, Haugaasen \& Peres 2005, Brearley et al. 2007, Cannon et al. 2007), with little attention paid to woody plants of the forest understory. However, the phenology of understory trees is of great relevance to understanding tropical plant-animal interactions, especially mutualisms between pollinating and seed-dispersing vertebrates and the plants they feed on. Phenologies of understory trees and shrubs are likely to differ from those of canopy plants due to their smaller size, shorter lifespan, lower visibility to potential mutualists, and lower levels of light (carbon) available to allocate to reproduction.

Our second goal was to examine how phenological patterns scale up from the level of the individual to the landscape, a scaling process dependent upon the duration and the degree of synchrony of reproductive stages at lower levels. In tropical wet forest communities, flowers and fruits are available to mutualists and antagonists year-round with landscape-level phenology being the product of patterns that vary among individuals, populations and habitat types (Newstrom et al. 1994). Understanding whether year-round flower and fruit availability reflects year-round flowering and fruiting of individuals or species, or is the result of multiple asynchronous phenologies is critical to understanding the structure of species interaction networks (Bascompte 2009), the evolution of dietary specialization in animal communities and the potential for competition among plants for pollinating and dispersing mutualists (Snow 1965, Poulin et al. 1999).

Because species often vary greatly in their phenological patterns, we took initial steps towards determining if population-level and community-level patterns of fruiting phenology might be the product of selection exerted by biotic interactions. We did this by analyzing two potential important ecological variables that could influence the evolution of phenological patterns: crop size and susceptibility to pathogen attack. Plants producing crops of different sizes are likely to attract different suites of seed dispersers (Gautier-Hion et al. 1985, Wheelwright \& Janson 1985, Foster 1990, Carlo et al. 2003). Susceptibility to pathogen attack could reflect the degree to which fruits and seeds are chemically defended (Tewksbury et al. 2008) which likely affects disperser identity and the relative benefits of different phenological patterns (Cipollini \& Levey 1997). Phenological patterns at the species level may be constrained by their evolutionary history such that closely related species have similar phenologies despite divergence in current selective pressures. Thus, we included analyses that took into account nested patterns of relatedness among species.

We compared the temporal patterns of community-level phenology (i.e., both the proportions of plant species bearing fruit and fruit production rates) with frugivorous bird abundance, levels of pathogen attack, and rainfall at three sites differing in elevation. Communitylevel fruiting patterns are thought to influence frugivore movements, yet may in turn have been influenced by temporal variation in disperser abundance if effective seed dispersal is an important component of the fitness equation (Aizen 2003, Elzinga et al. 2007). Pre-dispersal attack by pathogens that cause fruits to rot (e.g., fungi, bacteria) or consumers that destroy seeds prior to dispersal (e.g., insect larvae) represent increased costs of dispersal due to wasted resources invested in seeds and fruit pulp. If attack rates vary in seasonally predictable ways, pathogens could also contribute to shaping temporal patterns of fruiting. Finally, because rainfall is a major axis of seasonality in these forests, influencing plant growth (Brearley et al. 2007), seed disperser behavior (Boyle et al. 2010), and likely pathogen populations, we related precipitation to community-level phenological patterns. 
To address these goals, we followed the reproductive phenology of marked individuals for one year in the understory of three forested sites in NE Costa Rica. We characterized phenological patterns following Newstrom et al. (1994) in a hierarchical fashion based on the number of reproductive bouts/yr at nested levels of organization. Because Newstrom et al. (1994) did not develop quantitative measures to differentiate the phenological classes they describe, we expand their framework by more explicitly articulating criteria for classification decisions. We also quantified the proportions of fruits lost to pre-dispersal pathogens and the relative abundance of seed-dispersing frugivorous birds.

\section{MATERIALS AND METHODS}

We studied phenology at three sites along an elevational gradient in and near the 47 572ha Braulio Carrillo National Park (BCNP). We monitored plants in each month of 2004, spending one week per site per month. We chose these sites because, despite their proximity ( $15 \mathrm{~km}$ between most distant sites), they span major biotic and abiotic gradients while sharing many plant species. Thus, they represent communities in which the same or closely-related plant species experience considerably different selective regimes potentially affecting phenology.

Our highest-elevation site was at $750 \mathrm{~m}$ (Rara Avis Reserve, 10¹7'3" N - 8402'47" $\mathrm{W})$. Forests at this site are classified as premontane pluvial (sensu Holdridge 1967), have a mean annual temperature of $22.3^{\circ} \mathrm{C}$, and receive a mean annual rainfall of $8267 \mathrm{~mm}( \pm$ SE $228 \mathrm{~mm}$ ). Our lowest-elevation site was at $100 \mathrm{~m}$ (La Selva Biological Station, 10²4'59”' $\left.\mathrm{N}-84^{\circ} 01^{\prime} 55^{\prime} \mathrm{W}\right)$. Forests at this site are classified as lowland tropical wet (Holdridge 1967), have a mean annual temperature of $25.6^{\circ} \mathrm{C}$, and receive a mean annual rainfall of $4306 \mathrm{~mm}$ $( \pm$ SE $101 \mathrm{~mm})$. Even during drier months, these sites receive substantial precipitation, with mean monthly rainfall ranging from 501$849 \mathrm{~mm}$ at Rara Avis and $168-533 \mathrm{~mm}$ at $\mathrm{La}$
Selva. The intermediate site was at $300 \mathrm{~m}$ in BCNP (near the Cantarrana refuge, 10'22'16" $\mathrm{N}-84^{\circ} 02^{\prime} 45^{\prime \prime} \mathrm{W}$ ), and is located roughly equidistant between the other two sites. Using rainfall data collected at $300 \mathrm{~m}$ in 2004 , we estimated annual rainfall to be $6845 \mathrm{~mm}$. Hereafter we refer to these three sites by their elevations. Mean daily temperature varies little (at $100 \mathrm{~m}$, $25^{\circ} \mathrm{C} \pm \mathrm{SD} 1.3^{\circ} \mathrm{C},>23 \mathrm{yr}$ daily records), and seasonal patterns of rainfall are similar along the gradient. At all elevations, May-Aug and Dec are the rainiest months and Feb-Apr the driest months (Sanford et al. 1994, La Selva, Rara Avis, and W. A. Boyle, unpublished data).

We monitored phenology on 226 individually-marked plants belonging to 35 species in the Melastomataceae and Rubiaceae (Table 1). We chose species due to their importance in the diets of understory frugivorous birds based on fecal samples (Rosselli 1989, Loiselle \& Blake 1990, Stiles \& Rosselli 1993, Loiselle \& Blake 1999, Boyle et al. 2011) and traits indicative of avian seed dispersal (fruit size, color and fleshiness). Voucher specimens of all species in this study were deposited at the Museo Nacional de Costa Rica, INBio and the Missouri Botanical Garden. We measured plant diameter at breast height (dbh), basal diameter, and estimated height to the nearest $0.5 \mathrm{~m}$. We visited each marked plant at the beginning of a week's sampling period, noted if it bore buds or flowers, and counted all unripe and ripe fruits.

Phenological classification: We followed Newstrom et al. (1994) framework which differs from previous tropical phenological classifications (Frankie et al. 1974, Gentry 1974, Bawa 1983) in explicitly differentiating between patterns repeating at nested levels of organization from inflorescences up through individuals, populations and communities. Although Newstrom et al. (1994) identified multiple attributes that contribute to the diversity of phenological patterns (e.g., regularity, duration, amplitude), their classification relies on the number of reproductive bouts per year at any given level of biological organization: (1) continual, with new reproductive structures 
TABLE 1

All 35 species in the Melastomataceae and Rubiaceae included in this study summarizing phenological pattern (i.e., annual (A), sub-annual (S), continual (C)), minimum reproductive size, $n$ marked individuals, plant density by elevation, and month of maximum fruit production rate

\begin{tabular}{|c|c|c|c|c|c|c|c|c|c|c|c|c|}
\hline \multirow{3}{*}{ Species } & \multirow{3}{*}{$\begin{array}{l}\text { Min. } \\
\text { repro. } \\
\text { size }\end{array}$} & \multirow{2}{*}{\multicolumn{3}{|c|}{$n$ marked individs. }} & \multirow{2}{*}{\multicolumn{3}{|c|}{ Density/ha }} & \multirow{2}{*}{\multicolumn{4}{|c|}{$\begin{array}{l}\text { Fruiting phenology } \\
\text { population }\end{array}$}} & \multirow{3}{*}{$\begin{array}{l}\text { land- } \\
\text { scape }\end{array}$} \\
\hline & & & & & & & & & & & & \\
\hline & & $100 \mathrm{~m}$ & $300 \mathrm{~m}$ & $750 \mathrm{~m}$ & $100 \mathrm{~m}$ & $300 \mathrm{~m}$ & $750 \mathrm{~m}$ & Indiv & $100 \mathrm{~m}$ & $300 \mathrm{~m}$ & $750 \mathrm{~m}$ & \\
\hline \multicolumn{13}{|l|}{ Melastomataceae } \\
\hline${ }^{\mathrm{b}}$ Clidemia densiflora (Standl.) Gleason & 0.7 & 8 & 6 & 0 & 33 & 30 & 0 & $\mathrm{~S} / \mathrm{C} / \mathrm{A}$ & $\mathrm{S}$ & $\mathrm{C}$ & & $\mathrm{C}$ \\
\hline Clidemia hammelii Almeda & 1 & 0 & 3 & 0 & 0 & 70 & 0 & $\mathrm{~S}$ & & $\mathrm{~S}$ & & \\
\hline Clidemia ombrophila Gleason & 1 & 2 & 3 & 0 & 2 & 2 & 20 & $\mathrm{~S} / \mathrm{C}$ & & $\mathrm{C}$ & & $\mathrm{S}$ \\
\hline Conostegia cf bracteata & 2 & 6 & 1 & 0 & 2 & 2 & 0 & $\mathrm{C} / \mathrm{S}$ & & & & \\
\hline Conostegia lasciopoda Benth & 5.5 & 0 & 3 & 0 & 7 & 2 & 0 & A & & & & \\
\hline${ }^{\mathrm{a} C}$ Conostegia micrantha Standl. & 3.5 & 8 & 5 & 14 & 2 & 2 & 80 & $\mathrm{~A}$ & A & A & $\mathrm{A}$ & A \\
\hline Conostegia rhodopetala Donn. Sm. & & 0 & 0 & 1 & 0 & 0 & 2 & & & & & \\
\hline${ }^{\mathrm{b}}$ Conostegia rufescens Raudin & 1.1 & 0 & 4 & 8 & 0 & 90 & 530 & A & & A & A & A \\
\hline Melastomataceae sp. 1 & 7.8 & 1 & 0 & 0 & 2 & 0 & 0 & $\mathrm{~A}$ & & & & \\
\hline $\begin{array}{l}\text { Graffenrieda galleotii (Naudin) L.O. } \\
\text { Williams }\end{array}$ & 2 & 0 & 3 & 0 & 20 & 10 & 0 & A & & & & \\
\hline $\begin{array}{l}\text { aHenriettea tuberculosa (Donn. Sm.) L.O. } \\
\text { William }\end{array}$ & 2.5 & 14 & 6 & 6 & 47 & 30 & 40 & $\mathrm{~S} / \mathrm{A}$ & $\mathrm{S}$ & $\mathrm{S}$ & $\mathrm{S}$ & $\mathrm{S}$ \\
\hline Leandra grandifolia Cogn. & 1.6 & 0 & 1 & 0 & 0 & 2 & 0 & $\mathrm{~S}$ & & & & \\
\hline Miconia affinis DC. & & 1 & 0 & 0 & 2 & 0 & 0 & & & & & \\
\hline Miconia appendiculata Triana & & 3 & 1 & 0 & 2 & 2 & 0 & & & & & \\
\hline Miconia dorsiloba Gleason & 2 & 0 & 5 & 0 & 0 & 10 & 0 & $\mathrm{~S}$ & & $\mathrm{~S}$ & & \\
\hline${ }^{\mathrm{a} M i c o n i a}$ gracilis Triana & 2 & 6 & 5 & 8 & 2 & 10 & 2 & $\mathrm{~A} / \mathrm{S}$ & $\mathrm{A}$ & A & A & A \\
\hline Miconia grayumii Alameda & 3.9 & 1 & 0 & 0 & 2 & 0 & 0 & $\mathrm{C}$ & & & & \\
\hline Miconia ligulata Almeda & 2 & 0 & 2 & 0 & 0 & 40 & 0 & & & & & \\
\hline Miconia loreyoides Triana & 2 & 0 & 0 & 1 & 0 & 0 & 20 & A & & & & \\
\hline Miconia multispicata Naudin & & 0 & 2 & 0 & 0 & 2 & 0 & & & & & \\
\hline Miconia nervosa (J. E. Sm.) Triana & 1 & 4 & 1 & 0 & 13 & 2 & 0 & $\mathrm{~A} / \mathrm{S}$ & A & & & A \\
\hline${ }^{\mathrm{b}}$ Miconia simplex Triana & 1.3 & 6 & 3 & 0 & 27 & 40 & 0 & $\mathrm{C} / \mathrm{S}$ & S & $\mathrm{S}$ & & $\mathrm{S}$ \\
\hline Miconia sp. G & & 1 & 0 & 0 & 2 & 0 & 0 & & & & & \\
\hline Ossaea brenesii Standl. & 2.3 & 0 & 0 & 1 & 0 & 0 & 30 & $\mathrm{C}$ & & & & \\
\hline${ }^{\mathrm{a} O}$ Sssaea macrophylla (Benth.) Cogn. & 0.9 & 6 & 5 & 7 & 7 & 210 & 40 & $\mathrm{~S} / \mathrm{C}$ & $\mathrm{S}$ & $\mathrm{S}$ & $\mathrm{S}$ & $\mathrm{S}$ \\
\hline Ossaea robusta (Triana) Cogn. & 1.5 & 1 & 0 & 8 & 2 & 0 & 150 & $\mathrm{C}$ & & $\mathrm{C}$ & & $\mathrm{C}$ \\
\hline \multicolumn{13}{|l|}{ Rubiaceae } \\
\hline Coussarea talamancana Standl. & 4.9 & 0 & 3 & 0 & 7 & 20 & 0 & A & & & & \\
\hline Palicourea gomezii C. M. Taylor & 3.5 & 0 & 0 & 7 & 0 & 40 & 20 & $\mathrm{C} / \mathrm{S}$ & & & $\mathrm{S}$ & \\
\hline Psychotria acuminata Benth. & 2.2 & 1 & 0 & 0 & 2 & 0 & 0 & $\mathrm{~S}$ & & & & \\
\hline bPsychotria buchtienii Standl. & 0.7 & 6 & 0 & 10 & 100 & 20 & 280 & $\mathrm{~S} / \mathrm{C}$ & S & & $\mathrm{S}$ & $\mathrm{C}$ \\
\hline Psychotria elata (Sw.) Hammel & 1 & 0 & 0 & 2 & 13 & 160 & 270 & $\mathrm{~S}$ & & & & \\
\hline Psychotria hispidula Standl. ex Steyerm. & 1.6 & 0 & 1 & 0 & 0 & 10 & 0 & A & & & & \\
\hline Psychotria microbotrys Ruiz ex Standl. & 1.2 & 0 & 1 & 1 & 7 & 2 & 10 & $\mathrm{~S} / \mathrm{A}$ & & & & \\
\hline bPsychotria suerrensis Donn. Sm. & 1 & 4 & 8 & 0 & 67 & 90 & 0 & $\mathrm{~A}$ & $\mathrm{~A}$ & $\mathrm{~A}$ & & A \\
\hline Rudgea cornifolia (Kunth) Standl. & 4.7 & 1 & 0 & 0 & 2 & 0 & 0 & A & & & & \\
\hline
\end{tabular}

a. Species for which we compared phenological patterns at all three elevations.

b. Species for which we compared phenological patterns at two of the three elevations.

c. We estimated population level patterns for all species represented by $\geq 3$ reproductive individuals/site, and landscape level where we had $\geq 3$ reproductive individuals from $\geq 2$ sites. When species varied in phenology among individuals, we note the more common pattern first. 
being produced more or less year-round; (2) sub-annual, with more than one discrete reproductive bout per year; (3) annual, with a single reproductive bout per year; and (4) supraannual, with reproductive bouts occurring less than once per year.

The ways in which phenological patterns scale up from one level to the next depend upon the degree of reproductive synchrony at lower levels (e.g., proportions of branches, individuals, species). Newstrom et al. (1994) did not quantitatively describe criteria for determining what proportion of units reproducing constituted "synchronous" reproduction, and furthermore, these authors considered only flowering phenology, whereas we consider the entire reproductive episode, especially focusing on fruiting phenology. Consequently, classification of some patterns in our dataset depended upon articulating explicit criteria and numeric thresholds to make this system a useful tool for comparisons among studies. We summarize these criteria in table 2. Note that flowering and fruiting can lead to different phenological classifications if either fruit maturation periods vary considerably or if pathogen attack results in loss of all developing fruits following flowering. When patterns of fruiting and flowering differed, we based our classification upon fruiting patterns due to our interest in fruitfrugivore interactions.

Correlates of species phenologies: We analyzed the correlates of species' phenologies in two ways. First, we examined correlates of patterns evident at the individual level. Because patterns were fairly consistent at the individual level in species reproducing once per year but more variable in those reproducing more frequently, we grouped species having more than one reproductive bout per year (sub-annual and continual). Second, in species for which we could characterize communitylevel or landscape-level patterns, we examined

TABLE 2

Criteria used to characterize phenological patterns at the individual-, population-, community-, and landscape-levels

\begin{tabular}{ll} 
& \multicolumn{1}{c}{ Continual $(\mathrm{C})$} \\
Individual & $>1$ reproductive bout/yr/individ- \\
(branches on & ual; gaps in production of new \\
plant) & flowers/fruits $\leq 2$ mo; new buds \\
& $\begin{array}{l}\text { produced simultaneous with } \\
\text { development of unripe fruit. }\end{array}$
\end{tabular}

Population (individuals within species/ site)

Community (species at site)

Landscape (individuals or species at all sites)

\begin{abstract}
No strong seasonal peaks in fruiting/flowering; never more than 1 consecutive mo where $\leq 20 \%$ of individuals flowering or fruiting.

Some species flowering/fruiting in most months; never more than 1 consecutive mo where $\leq 20 \%$ of species flowering/ fruiting.
\end{abstract}
Some species/individuals flowering and fruiting in most months; never more than 1 con- secutive mo where $\leq 20 \%$ of species/individuals flowering/ fruiting.

\section{Sub-annual (S)}

$>1$ reproductive bout/yr/individual; gaps in production of new flowers/fruits > 2 mo; new buds sometimes produced simultaneous with development of unripe fruit.

$>1$ peak in fruiting/flowering/ $\mathrm{yr}$; periods in which $\leq 20 \%$ of individuals flowering/fruiting longer than $\geq 2$ mo.

$>1$ distinct seasonal peak in flowering/fruiting; periods in which $\leq 20 \%$ of species flowering/fruiting $\geq 2 \mathrm{mo}$.

$>$ distinct seasonal peak in flowering/fruiting; periods in which $\leq 20 \%$ of species/individuals flowering/fruiting $\geq 2 \mathrm{mo}$.

\section{Annual (A)}

1 reproductive bout/yr/individual; production of new flowers/fruits initiated on different branches \pm 1 mo of each other; buds develop and fruit ripens at different times.

1 seasonal peak in fruiting/flowering/yr; all individuals with peak flowering/fruiting \pm 1 mo of each other.

1 seasonal peak in fruiting/flowering/yr; $\geq 3$ mo during which $\leq 20 \%$ of species flowering/ fruiting; peak flowering/ fruiting \pm 3 mo of each other.

1 seasonal peak in fruiting/ flowering/yr; $\geq 3$ mo during which $\leq 20 \%$ of species/individuals flowering/fruiting; peak flowering /fruiting of species/ individuals \pm 3 mo of each other. 
correlates of phenological strategy at these broader scales, using patterns derived from all reproductive individuals within each species. With each approach, we considered the relationship between phenological pattern (i.e., continual, sub-annual or annual) and crop size (Eriksson \& Ehrlén 1991), levels of pathogen attack, and the role of phylogenetic relatedness in constraining phenological strategy.

To quantify fruit crop size and levels of pathogen attack, we estimated standing crop of ripe and rotting fruits and daily production rates of ripe fruits and rates of pathogen attack. We estimated these rates by marking and following 1-11 infructescences (mean=4.1 infructescences/plant) one week each month. On each marked infructescence, we counted all ripe, unripe and pathogen-attacked fruits at the beginning of the sampling week, removing attacked fruits. We re-counted fruits at the end of the sampling week (mean $=4.9 \mathrm{~d}$ between checks) and estimated per-infructescence ripening rates as $\left[n\right.$ unripe $1^{\text {st }}$ check $]-[n$ unripe $2^{\text {nd }}$ check $]-\left[n\right.$ attacked $2^{\text {nd }}$ check $]$ and perinfructescence daily attack rates as $[n$ attacked $2^{\text {nd }}$ check $] /[n$ d between checks $]$. We estimated daily production and attack rates per plant during each month as the mean per-infructescence production (or attack) multiplied by the total $n$ infructescences bearing fruit that month. We used data from all individuals bearing fruit in that month and $\ln$-transformed fruit counts and daily rates prior to analysis. We used general linear models to evaluate the relationship between phenological pattern (i.e., continual, sub-annual or annual) and both crop size and pathogen attack separately, as well as models that included both these factors and genus (nested within family) to account for phylogenetic constraints.

Community-level correlates: We used patterns of community-level phenology (proportions of species) and fruit abundance (daily production rates of ripe fruit) at the three sites to evaluate some of the potential biotic and abiotic correlates of fruiting patterns (i.e., frugivore abundance, pathogen attack rates and rainfall). To estimate community-level fruit production rates, we estimated the density of individuals/species by surveying 10 (at the $300 \mathrm{~m}$ and $750 \mathrm{~m}$ sites) or 15 (at the $100 \mathrm{~m}$ site) 0.01 -ha belt transects $(2 \times 50 \mathrm{~m})$ systematically spaced $\geq 100 \mathrm{~m}$ apart. Along each transect, we identified, recorded reproductive status, and measured the dbh, basal diameter, and height of all plants in the Melastomataceae and Rubiaceae. We estimated the minimum size at which a species is reproductive by three sets of measurements (basal diameter, diameter at breast height and height of tree) for all marked individuals and all individuals entering into plant transects. We chose the best predictor of reproductive status by conducting three sets of logistic regression analyses. Because basal diameter was more strongly associated with reproductive status than either dbh or tree height, we used basal diameter $(\mathrm{cm})$ as the measure of minimum reproductive size. We then searched all records of plants from all sites for the smallest individual found flowering or fruiting and used this as the minimum reproductive size for the species as a whole. We then used the number of individuals in transects $\geq$ this size to estimate the density of reproductive-sized individuals/ species/ha at each elevation (Table 1).

We multiplied the mean per-individual estimates of fruit production each month by the number of reproductive-sized individuals/ha for each species. In a few cases, marked plant species did not occur along plant transects, yielding estimates of fewer than 10 individuals per ha. We arbitrarily assigned these species densities of two individuals/ha as a conservative estimate of their abundance. Finally, we summed the monthly rates for all species at a site to obtain overall production rate estimates by month and site.

To determine patterns of seasonal abundance of dispersers at each elevation, we captured birds for $5-7 \mathrm{~d}$ at each site each month in $6-16$ mist nets $(12 \mathrm{~m}$ wide $\mathrm{x} 3 \mathrm{~m}$ tall, $38 \mathrm{~mm}$ mesh). We located nets in the same places in successive months in the understory of oldgrowth forest in the vicinity of marked plants. We opened mist nets at 06:00, and kept them 
open until noon or until rain began, checking nets every $20 \mathrm{~min}$. This capture effort resulted in 3069 captures in 13321 mist-net-hours (mnh). We classified birds as frugivores and potential seed dispersers based on Stiles \& Skutch (1989). We banded birds, collected data on age, sex, diet, and morphology for other studies (Boyle 2008, Boyle et al. 2011), then released birds at the capture site.

We used monthly rainfall totals from the $100 \mathrm{~m}$ and $750 \mathrm{~m}$ sites (derived from 20-40yr data) and interpolated mean monthly amounts for the $300 \mathrm{~m}$ site based on regression equations using daily measurements from all three sites in 2004. We examined the relationships among community-wide phenological patterns, disperser abundance, pathogen attack and rainfall, at each site separately, accounting for the temporal autocorrelation of monthly data in ANOVA models by incorporating month coded numerically and testing for significance of the time* predictor variable interaction term.

\section{RESULTS}

Phenological diversity: Of the 226 individuals of 35 plant species that we monitored, 168 individuals of 29 species reproduced during 2004 (Table 1). The total duration of the reproductive period (month of first buds to last month of fruiting) varied from $6 \mathrm{mo}$ (e.g., Miconia nervosa) to $12 \mathrm{mo}$ (e.g., Psychotria suerrensis). However, even in plants exhibiting annual phenological patterns, reproduction was relatively protracted: on average, individuals were non-reproductive for only 2.6 mo of the year. Individuals exhibiting continual phenologies bore buds $51 \%$ of the year, flowers $38 \%$ of the year, unripe fruit $76 \%$ of the year and ripe fruit $40 \%$ of the year. Most individuals bore reproductive structures in every month of the year. Within species, phenological patterns frequently differed among individuals, with continual and sub-annual patterns, or sub-annual and annual patterns occurring in the same species (Table 1).

Fifteen species were represented by $\geq 3$ reproductive individuals at two or more sites permitting examination of phenological patterns within species at higher levels of organization (Table 1; Fig. 1; see Appendix for graphical representations of phenologies of all species at all sites in online version). Among the eight species for which we were able to characterize phenological patterns at more than one site, only in Clidemia densiflora did the population-level patterns differ among sites (Table 1; Appendix). Phenological patterns at the landscape level typically mirrored the population-level patterns within species, with three exceptions: (1) in Clidemia densiflora,

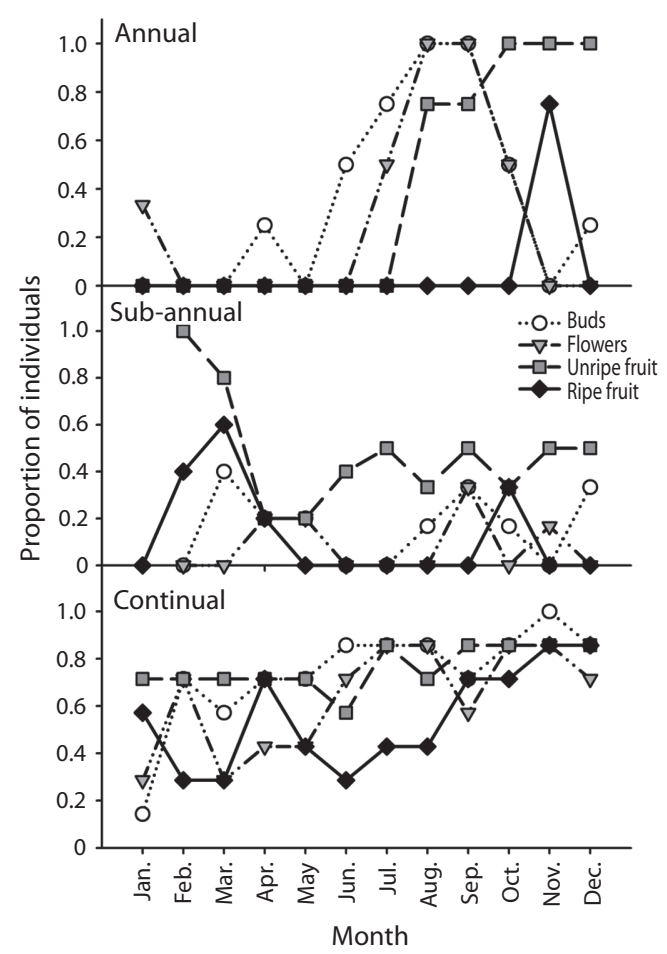

Fig. 1. Examples of each of the three phenological patterns displayed by plants in this study. Figures depict populationlevel patterns, represented by the proportions of individuals (of the total reproductive individuals monitored of that species at a site) bearing buds (open circles / dotted lines), open flowers (grey triangles/dot-dashed lines), unripe fruit (grey squares/dashed lines), and ripe fruit (black diamonds/black lines). The annual phenological pattern is exemplified by Conostegia rufescens at $300 \mathrm{~m}$, the subannual pattern is exemplified by Psychotria buchtienii at $100 \mathrm{~m}$, and the continual pattern is exemplified by Ossaea robusta at $750 \mathrm{~m}$. 
the landscape-level continual pattern was consistent with the population-level pattern at the $100 \mathrm{~m}$ site but not the $300 \mathrm{~m}$ site; (2) in Clidemia ombrophila, the continual pattern evident at the $300 \mathrm{~m}$ site shifted to a sub-annual pattern when additional reproductive individuals from the 100m site were included; and (3) in Psychotria buchtienii, sub-annual patterns at two sites (e.g., Fig. 1) were asynchronous enough that patterns over the broader geographic area were more accurately classified as continual. At the landscape scale, five species exhibited annual phenological patterns, and these were mirrored in annual patterns down to the level of the individual.

Because our study lasted only one year, our methods precluded detecting supra-annual reproductive cycles, which could result in a few species being incorrectly classified as having annual patterns or could account for some of the species we marked that did not reproduce in 2004. However, field observations, notes, and botanical collections assembled in the same region over 14 mo during 2001-2003 and 20072011 confirm that temporal patterns observed in 2004 represent repeatable phenomena in most, if not all, of the species (W. A. Boyle, unpubl. data).

Among species, phenological patterns were asynchronous, with the result that community-level patterns at all three sites (Fig. 2) as well as the overall landscape-level patterns were continual. Even when we considered only the populations exhibiting annual phenological patterns, all phenological stages were present in at least one species in all months at all sites. Likewise, sub-annual fruiters exhibited considerable asynchrony, with no two species having both peak fruiting periods in the same months. Ripe fruits were produced by a similar proportion of the species we studied at all three sites throughout the year (Fig. 2). The month with the fewest species producing ripe fruit differed among sites (Feb at 750m, Mar at $300 \mathrm{~m}$ and May at $100 \mathrm{~m}$ ), but occurred during or within one month of the drier season at all sites (Feb-Apr).
In summary, the reproductive phenologies of the species in the Melastomataceae and Rubiaceae that we studied exhibited considerable diversity in terms of the number of reproductive bouts per year as well as the timing and synchrony of those bouts within and among individuals. However, regardless of where a plant grew, individual level patterns were consistent within species.

Correlates of species phenological patterns: Individual-level phenological patterns were not related to the size of the fruit crop produced $(l n$-transformed mean standing crop of ripe fruit, $\mathrm{t}_{24}=-1.6, \mathrm{p}=0.129 ; \ln$-transformed

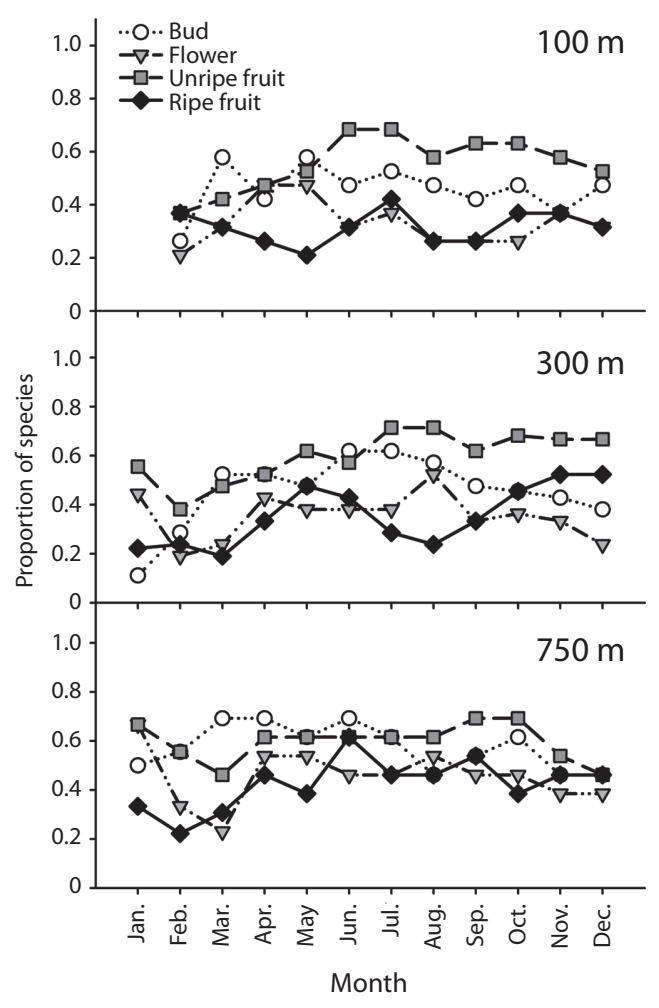

Fig. 2. Continual community-level phenological patterns at all three of the sites in NE Costa Rica we studied: $750 \mathrm{~m}$ at the Rara Avis reserve (top panel), 300m near the Cantarrana refuge in Braulio Carrillo National Park (middle panel), and $100 \mathrm{~m}$ at La Selva Biological station (lower panel). Values represent the proportion of species monitored at each site bearing buds (open circles), flowers (light grey triangle), unripe fruit (dark grey boxes) and ripe fruit (black diamonds) during each month's monitoring period. 
ripening rate, $\mathrm{t}_{25}=-1.6, \mathrm{p}=0.113$ ) nor to the species' level of pathogen attack ( $l n$-transformed mean standing crop of rotten fruit, $\mathrm{t}_{23}=-0.9$, $\mathrm{p}=0.396$; $\ln$-transformed rotting rate, $\mathrm{t}_{23}=-0.1$, $\mathrm{p}=0.921)$. Combining standing crop measures with genus (nested within family) revealed that together, these variables were not related to phenological patterns (effect likelihood $\chi^{2}=11.5, \mathrm{df}=10, \mathrm{p}=0.317$ ).

Restricting analyses to only those species for which we could characterize phenological patterns at the population or landscape level did not change the results. A species' phenological pattern at these higher levels was not related to the average size of its fruit crop (ln-transformed mean standing crop of ripe fruit, $\mathrm{F}_{2,12}=0.7, \mathrm{p}=0.530$; $\ln$-transformed ripening rate, $\mathrm{F}_{2,12}=0.5, \mathrm{p}=0.608$ ) nor to its level of pathogen attack ( $\ln$-transformed mean standing crop of rotten fruit, $\mathrm{F}_{2,12}=0.1, \mathrm{p}=0.919 ; \ln$ transformed rotting rate, $\mathrm{F}_{2,12}=0.3, \mathrm{p}=0.729$ ). Including genus nested within family was not possible given the reduced sample size in this analysis. However, accounting for phylogenetic effects by including plant family together with standing crop measures revealed that these variables were not related to phenological patterns (effect likelihood $\chi^{2}=3.8, \mathrm{df}=6, \mathrm{p}=0.698$ ).

Correlates of community-level phenological patterns: Although the proportions of species bearing ripe fruit did not fluctuate greatly over the course of the year or among elevations (Fig. 2), the production rates of ripe fruits did fluctuate considerably over these temporal and spatial scales (Fig. 3a), with peaks in fruit production in Jun at $100 \mathrm{~m}$, Oct at $300 \mathrm{~m}$, and both Jul and Oct at $750 \mathrm{~m}$. Peaks in fruit production were primarily driven by one or two species at each site bearing very large fruit crops.

Table 3 summarizes the relationships between phenology and rainfall, disperser abundance, and pathogen attack. The nature of these relationships depended upon the site and the response variable considered (proportion of species bearing ripe fruit or fruit production rates). The only rainfall model that explained a significant portion of the variation was that of fruit production rates at the $300 \mathrm{~m}$ site (whole model, $\mathrm{F}_{3,7}=4.8, \mathrm{p}=0.041$; Table 3 ). As rainfall increased, fruit production rates tended to decrease (rainfall partial effect test, $\left.\mathrm{F}_{1,7}=5.3, \mathrm{p}=0.055\right)$.

Nearly half ( $n=1462)$ of bird captures were of seed-dispersing frugivores belonging to 41 species. Of these individuals, 741 (51\%; 12 species) were altitudinal migrants and 301 (21\%; 4 species) were long-distance migrants (Boyle 2006). Seasonal movements of migrants

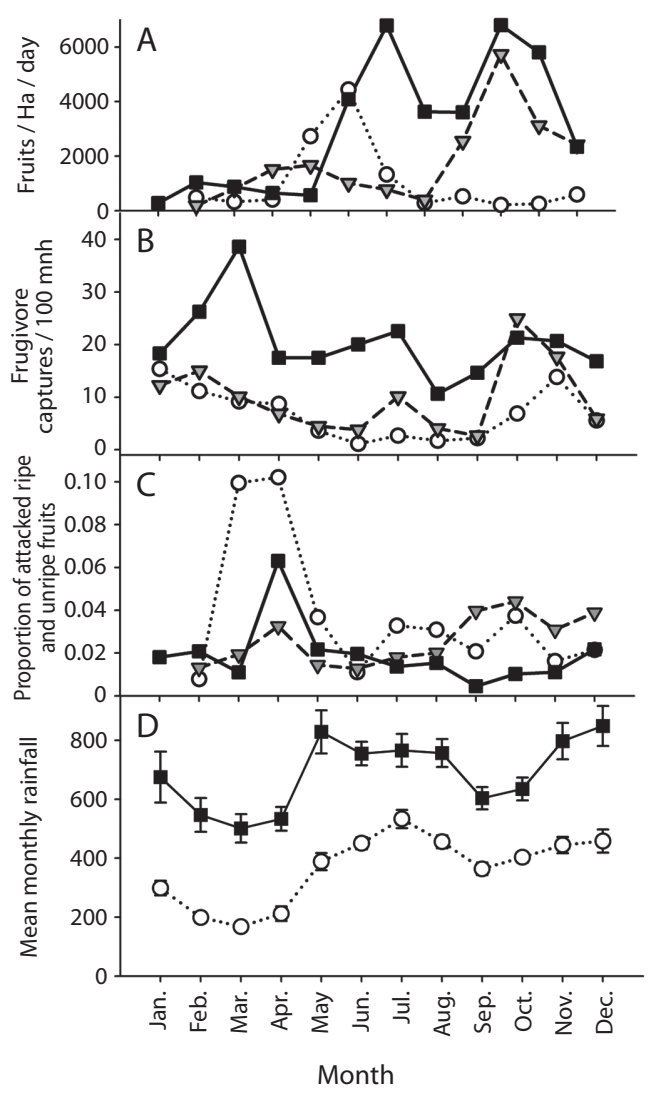

Fig. 3. Landscape-scale patterns of fruit production rates $(N$ fruits ripened/d/Ha; panel A), capture rates of frugivorous birds (panel B), proportions of the total number of fruits that were attacked by pathogens (panel C), and mean $( \pm \mathrm{SE})$ monthly rainfall (panel D) in 2004. The highest elevation site at $750 \mathrm{~m}$ is represented by black squares and solid lines, the $300 \mathrm{~m}$ site is represented by grey diamonds and dashed lines, and the $100 \mathrm{~m}$ site is represented by open circles and dotted lines. 
TABLE 3

Results of statistical models examining the temporal correlations between community-level fruiting phenology, rainfall, seed disperser abundance and pathogen attack

\begin{tabular}{|c|c|c|c|c|c|c|c|c|c|}
\hline \multirow{2}{*}{ Analysis } & \multicolumn{3}{|c|}{$100 \mathrm{~m}$} & \multicolumn{3}{|c|}{$300 \mathrm{~m}$} & \multicolumn{3}{|c|}{$750 \mathrm{~m}$} \\
\hline & $\mathrm{F}$ & $\mathrm{df}$ & $\mathrm{p}$ & $\mathrm{F}$ & df & $\mathrm{p}$ & $\mathrm{F}$ & df & $\mathrm{p}$ \\
\hline \multicolumn{10}{|l|}{ Proportion spp. fruiting \& rainfall } \\
\hline whole model & 1.5 & 3.7 & 0.292 & 3.1 & 3.8 & 0.089 & 2.0 & 3.8 & 0.187 \\
\hline month*rainfall interaction & 4.0 & 1.7 & 0.084 & 0.0 & 1.8 & 0.968 & 1.5 & 1.8 & 0.252 \\
\hline \multicolumn{10}{|l|}{ Fruit production rates $\&$ rainfall } \\
\hline whole model & 2.8 & 3.7 & 0.122 & 4.8 & 3.7 & 0.041 & 3.6 & 3.8 & 0.064 \\
\hline month*rainfall interaction & 1.2 & 1.7 & 0.307 & 2.3 & 1.7 & 0.176 & 1.9 & 1. 8 & 0.202 \\
\hline \multicolumn{10}{|c|}{ Proportion spp. fruiting \& disperser abundance } \\
\hline whole model & 0.5 & 3.7 & 0.722 & 3.8 & 3.8 & 0.059 & 1.9 & 3.8 & 0.198 \\
\hline month*disperser interaction & 0.1 & 1.7 & 0.843 & 1.6 & 1. 8 & 0.248 & 0.1 & 1.8 & 0.732 \\
\hline \multicolumn{10}{|c|}{ Fruit production rates $\&$ disperser abundance } \\
\hline whole model & 4.3 & 3.7 & 0.052 & 7.6 & 3.7 & 0.013 & 4.7 & 3.8 & 0.036 \\
\hline month*disperser interaction & 5.9 & 1.7 & 0.045 & 2.5 & 1.7 & 0.156 & 3.2 & 1.8 & 0.113 \\
\hline \multicolumn{10}{|c|}{ Pathogen attack \& proportion spp. fruiting } \\
\hline whole model & 0.2 & 3.7 & 0.899 & 2.0 & 3.7 & 0.200 & 1.4 & 3.8 & 0.303 \\
\hline month*pathogen interaction & 0.1 & 1.7 & 0.822 & 0.3 & 1.7 & 0.602 & 0.1 & 1.8 & 0.791 \\
\hline \multicolumn{10}{|c|}{ Pathogen attack \& fruit production rates } \\
\hline whole model & 0.8 & 3.7 & 0.556 & 5.2 & 3.8 & 0.034 & 4.2 & 3.8 & 0.048 \\
\hline month*pathogen interaction & 0.3 & 1.7 & 0.585 & 0.6 & 1.8 & 0.461 & 1.5 & 1.8 & 0.254 \\
\hline
\end{tabular}

created considerable seasonality of potential seed dispersers at all elevations (Fig. 3b).

Disperser abundance was related to fruit production rates at all three sites, but was not related to the proportion of species bearing fruits at any site. The nature of the relationship between dispersers and fruit production rate differed among sites. At only the $300 \mathrm{~m}$ site was this relationship positive. At the other two sites, high fruit production rates were associated with low numbers of potential dispersers. At none of the three sites did the month of peak proportions of species bearing ripe fruit coincide with the month of peak disperser abundance, and only at $300 \mathrm{~m}$ did dispersers and fruiting phenology peak within one month of each other.

A diverse assemblage of organisms attacked fruits and seeds prior to dispersal. Evidence of pathogen attack included holes, tumor-like growths, discoloring, hardening, premature softening, filamentous webs, and mould. Rates of fruit pathogen attack varied greatly among species (e.g., some like Miconia grayumii lost almost their entire fruit crop, whereas others such as Rudgea acuminata and Miconia loreyoides lost almost no fruits). Incidence of pathogen attack also differed considerably among sites; mean $( \pm \mathrm{SE})$ attack rates varied from $4.5( \pm 3.5)$ fruits/ plant/d at $750 \mathrm{~m}$, to $15.2( \pm 2.9)$ fruits/plant/d at $100 \mathrm{~m}$. The proportions of fruits attacked showed similar trends (mean \pm SE monthly proportions attacked; $750 \mathrm{~m}, 0.019 \pm 0.006 ; 300 \mathrm{~m}$, $0.025 \pm 0.006 ; 100 \mathrm{~m}, 0.038 \pm 0.007)$. However, pathogen attack was not related to the proportion of species producing fruit at any site. At the $300 \mathrm{~m}$ site, increases in fruit production rates were associated with increases in the proportion of fruits attacked (pathogen attack partial effect test, $\mathrm{F}_{1,7}=4.8, \mathrm{p}=0.063$ ). In only one of the models that we evaluated (disperser abundance and fruit production rates at the $100 \mathrm{~m}$ site) did there appear to be any temporal autocorrelation (i.e., significant interaction between the main effect and month).

In general, temporal patterns of fruit production rates were better explained by the biotic and abiotic correlates we examined than 
were the proportions of species bearing ripe fruit (Table 3). Although several of the associations were statistically significant, results were inconsistent from site to site, and were not always associated in the ways predicted if mutualists and antagonists influence fruiting phenology of plant species they interact with.

\section{DISCUSSION}

Phenologies of plants growing in yearround warm, wet environments are freed from the constraints that limit the number and the timing of reproductive bouts. As a consequence, a diversity of reproductive strategies is viable, and these strategies can be shaped by a broad set of selective pressures. We found great phenological diversity, even in a narrow taxonomic subset of plants growing in one stratum of tropical wet forest. The number of reproductive bouts per year, and the timing, duration, and synchrony of those bouts varied to some extent among individuals of the same species, and to a large extent among populations of different species. Patterns at the individual level were usually reflected at the population level. However, the idiosyncratic nature of specieslevel phenological patterns was obscured at the community-level where we found little temporal or spatial variation in the proportion of fruiting species. This species-level variability and community-level constancy may well contribute to the lack of dietary specialization among frugivores (Schleuning et al. 2011) as well as the persistence of large frugivorous guilds in many tropical vertebrate and invertebrate lineages.

Phenologies of the species in this study have clearly been shaped in individualistic ways, probably by a much broader array of biotic and abiotic factors than considered in this study. Even among congeners (e.g., Miconia, Psychotria), all three of the phenological types were evident, and even in species of the same genus with the same phenological pattern (e.g., annual fruiting in Conostegia micrantha and $C$. rufescens), the timing of reproduction often differed. Given this species-level individuality, perhaps it is not surprising that no one correlate we studied was consistently related to phenological patterns at the community level.

Interestingly, not all possible phenological patterns were represented in this assemblage of plants. Notable was the absence of high amongindividual asynchrony in annual (or sub-annual) patterns. Such patterns are characteristic of reproduction in tropical New World fig (Ficus) species (Milton et al. 1982, Bronstein et al. 1990) and is one of the factors that permits persistence of specialization of the fig pollination mutualism. Frugivores are rarely as specialized in their interactions with plants as are fig wasps, and the phenological patterns of these plant groups may reflects these differences.

Within species, individuals had very similar phenologies, regardless of where they grew. The individual-level variation we did observe often appeared to reflect the health of the plant. For instance, some individuals ceased reproduction following defoliation by leafcutter ants (unpubl. data) and some lost entire fruit crops to pathogens. Additionally, in some species in which individuals exhibited either continual or sub-annual patterns, different classifications resulted from differences among individuals in the duration of non-reproductive periods. Likely such differences reflected variation in light or nutrient resources available for reproduction.

Although biotic interactions have long been proposed to shape plant phenologies (Rathcke \& Lacey 1985), abiotic constraints on phenologies are much better understood. We predicted that wet tropical forest would be the most likely environment in which to find evidence that mutualists and antagonists shape reproductive phenologies. Yet while phenological patterns were highly variable among species, they were not related to factors associated with seed dispersal or pathogen interactions. Although elevational differences in patterns of frugivore abundance implies that the potential exists for disperser-mediated selection on phenology, disperser abundance was not positively related to community-level fruiting patterns, in contrast to findings in different parts of the 
world (Noma \& Yumoto 1997, Poulin et al. 1999, Malizia 2001).

Failure to find the fingerprint of biotic selection on fruiting phenology could reflect one or a combination of factors. First, gene flow may swamp local selective pressures. Seed dispersers often range widely (Holbrook \& Smith 2000) and dispersal distances can reach nearly $1 \mathrm{~km}$ in this region (Sezen et al. 2005). This fact suggests that populations of plants with ranges spanning several hundred meters of elevation may exchange genes regularly, precluding adaptation to the local biotic environment. Second, the timing of fruiting may be constrained by selection on the timing of flowering and pollinator abundance. That is, biotic interactions may indeed shape phenologies, but of flowering rather than fruiting time. Similarly, phenology of vegetative growth may constrain fruiting time. Third, the movements of frugivores may not be predictable enough for selection to act on fruiting phenology (Jordano 1993). Indeed, migratory tendency appears to be highly evolutionarily labile (Able \& Belthoff 1998, Berthold 2001, Greenberg \& Marra 2005), perhaps especially in short-distance tropical migrants. Fourth, selection may be too weak at the seed dispersal stage for dispersers to affect phenology: effective dispersal location is unpredictable, and seeds experience high post-dispersal mortality (Wheelwright \& Orians 1982, Houle 1995). Finally, phenology of tropical species may also be constrained by abiotic conditions. While our analyses of rainfall and phenology suggest that water availability does not constrain reproduction, seasonal variation in solar irradiation (Zimmerman et al. 2007) likely influences the carbon available that plants require to produce fruit (Levey 1990, van Schaik et al. 1993). If so, the variability we found in phenological patterns may reflect species-specific physiological responses to local abiotic conditions.

The timing and intensity of pathogen attack has been given minimal attention as possible factors shaping plant phenologies. Potential causes of the general decrease in pathogen attack with increasing elevation may involve temperature $\left(3.3^{\circ} \mathrm{C}\right.$ difference in mean annual temperature between $100 \mathrm{~m}$ and $750 \mathrm{~m}$ ) or precipitation $(4306 \mathrm{~mm}$ at the $100 \mathrm{~m}$ site vs. $8267 \mathrm{~mm}$ at the $750 \mathrm{~m}$ site). Potentially, warmer (but drier) environments favor a greater abundance and/or diversity of insects, fungi and bacteria that attack fruits and seeds (Dalling et al. 2010). Alternatively, environmental differences could influence the incidence or effectiveness of chemical defenses employed by plants to defend reproductive structures from antagonists.

This study revealed a number of intriguing and unexplained patterns. Foremost among them is the striking variation in phenology among closely-related understory plants that are similar in so many other respects, running contrary to studies that report relative phylogenetic conservatism in tropical tree phenology (Bawa et al. 2003). Exploring the proximate and ultimate causes of this within-family and -genus variation would be valuable, especially in a more explicit phylogenetic framework than was possible in this study (Chazdon et al. 2003, Bolmgren \& Lönnberg 2005). The clear spatial patterns but apparent lack of interpretable seasonal patterns of pathogen attack in this study also begs for explanation. What factors result in plant species differing so dramatically in rates of pathogen attack? Can elevational patterns be explained by temporal or spatial distributions of different types of pathogens? (Biere \& Honders 1996, Mahoro 2003).

To better understand the degree to which climate and species interactions affect phenological patterns of tropical plants, studies in other tropical forests will be required, ideally spanning several years (Newstrom et al. 1992, Chapman et al. 2005). A full understanding of tropical phenologies is made difficult by the fact that measurements must be made frequently during the entire year. Nevertheless, studies such as this one that focus on testing hypotheses explaining a few components of diverse phenological patterns contribute to our understanding of the whole system. 


\section{ACKNOWLEDGMENTS}

B. Boyle, J. Brokaw, M. Burke, W. Goulding, M. Hill, C. Leumas, J. Montoya-Morera and J. Wolfe provided exceptional field assistance. B. Boyle, J. Gonzalez, B. Hammel, R. Kriebel, F. Morales, C. Taylor, O. Vargas and N. Zamora helped identify plants. J. Hurtado checked the Spanish. C. Conway, B. Enquist, D. Papaj and R. Steidl provided advice on the design and execution of this project. A. Bien, L. D. Gómez, staff of Rara Avis and La Selva Biological Station, MINAE, ACCVC, J. Guevara, R. Tenorio, and the University of Arizona's IACUC committee assisted with logistics, permits, and support in the field. This work was supported by the National Science Foundation (DEB-0410531), NSERC PGS-B and PDF fellowships to WAB, the Helen Battle Memorial Fellowship to WAB, and grants from the University of Arizona.

\section{RESUMEN}

En regiones con marcada estacionalidad, los patrones fenológicos de las plantas están limitados por el clima. Por el contrario, las plantas que crecen en bosques húmedos tropicales, no tienen tantas limitaciones abióticas y es por esto que el dosel presenta una diversidad muy rica en los patrones fenológicos de individuos, especies y comunidades. Sin embargo, es muy escasa la información sobre la descripción básica de los patrones fenológicos tropicales y de los procesos que los afectan. En este documento, presentamos los patrones fenológicos, a nivel de individuo, población y paisaje, a lo largo de un transecto altitudinal en Costa Rica, para dos familias dominantes de plantas leñosas (Melastomataceae y Rubiaceae) que son de gran importancia en la dieta de aves frugívoras. En este estudio, las plantas variaron en el número de brotes reproductivos por año, así como en el tiempo, duración y sincronización de la reproducción. Esta variación no estuvo relacionada con interacciones con mutualistas y antagonistas, ni aparentemente estuvo limitada por la filogenia. Los diversos patrones fenológicos de las especies fueron relativamente no estacionales a nivel de comunidad y paisaje. En conjunto, hubo poca evidencia de que los procesos abióticos hayan afectado los patrones fenológicos de fructificación. Estos resultados revelan una serie de patrones sin explicación aparente, y sugieren que los factores que determinan la fenología en los bosques relativamente no estacionales, funcionan de manera idiosincrática a nivel de especie.
Palabras clave: clima, aves frugívoras, patógenos, patrones fenológicos, dispersión de semillas, mutualismo, bosque húmedo tropical.

\section{REFERENCES}

Able, K.P. \& J.R. Belthoff. 1998. Rapid ‘evolution’ of migratory behaviour in the introduced house finch of eastern North America. Proc. R. Soc. B 265: 2063-2071.

Aizen, M.A. 2003. Influences of animal pollination and seed dispersal on winter flowering in a temperate mistletoe. Ecology 84: 2613-2627.

Anderson, D.P., E.V. Nordheim, T.C. Moermond, Z.B.G. Bi \& C. Boesch. 2005. Factors influencing tree phenology in Tai National Park, Cote d'Ivoire. Biotropica 37: 631-640.

Augspurger, C.K. 1983. Phenology, flowering synchrony, and fruit set of six neotropical shrubs. Biotropica 15: 257-267.

Bascompte, J. 2009. Disentangling the web of life. Science 325: 416-419.

Bawa, K.S. 1983. Patterns of flowering in tropical plants, pp. 394-410. In C.E. Jones \& R.J. Little (eds.). Handbook of Experimental Pollination Biology. Van Nostrand Reinhold, New York, New York, USA.

Bawa, K.S., H.S. Kang \& M.H. Grayum. 2003. Relationships among time, frequency, and duration of flowering in tropical rain forest trees. Am. J. Bot. 90: 877-887.

Berlin, K.E., T.K. Pratt, J.C. Simon, J.R. Kowalsky \& J.S. Hatfield. 2000. Plant phenology in a cloud forest on the island of Maui, Hawaii. Biotropica 32: 90-99.

Berthold, P. 2001. Bird migration: a novel theory for the evolution, the control and the adaptability of bird migration. J. Ornithol. 142: 148-159.

Bhat, D.M. 1992. Phenology of tree species of tropical moist forest of Uttara-Kannada District, Karnataka, India. J. Biosci. 17: 325-352.

Biere, A. \& S.J. Honders. 1996. Impact of flowering phenology of Silene alba and S. dioica on susceptibility to fungal infection and seed predation. Oikos 77 : 467-480.

Bolmgren, K. \& K. Lönnberg. 2005. Herbarium data reveal an association between fleshy fruit type and earlier flowering time. Int. J. Plant Sci. 166: 663-670.

Boyle, W.A. 2006. Why do birds migrate? The role of food, habitat, predation, and competition. Ph.D. Thesis, University of Arizona, Tucson, USA.

Boyle, W.A. 2008. Partial migration in birds: tests of three hypotheses in a tropical lekking frugivore. J. Anim. Ecol. 77: 1122-1128. 
Boyle, W.A., D.R. Norris \& C.G. Guglielmo. 2010. Storms drive altitudinal migration in a tropical bird. Proc. Roy. Soc. B 277: 2511-2519.

Boyle, W.A., C.J. Conway \& J.L. Bronstein. 2011. Why do some, but not all, tropical birds migrate? A comparative study of diet breadth and preference. Evol. Ecol. 25: 219-236.

Brearley, F.Q., J. Proctor, Suriantata, L. Nagy, G. Dalrymple \& B.C. Voysey. 2007. Reproductive phenology over a 10-year period in a lowland evergreen rain forest of central Borneo. J. Ecol. 95: 828-839.

Bronstein, J.L., P.H. Gouyon, C. Gliddon, F. Kjellberg \& G. Michaloud. 1990. The ecological consequences of flowering asynchrony in monoecious figs: a simulation study. Ecology 71: 2145-2156.

Bronstein, J.L. \& A. Patel. 1992. Causes and consequences of within-tree phenological patterns in the Florida strangling fig, Ficus aurea (Moraceae). Am. J. Bot. 79: 41-48.

Cannon, C.H., L.M. Curran, A.J. Marshall \& M. Leighton. 2007. Long-term reproductive behaviour of woody plants across seven Bornean forest types in the Gunung Palung National Park (Indonesia): suprannual synchrony, temporal productivity and fruiting diversity. Ecol. Lett. 10: 956-969.

Carlo, T.A., J.A. Collazo \& M.J. Groom. 2003. Avian fruit preferences across a Puerto Rican forested landscape: pattern consistency and implications for seed removal. Oecologia 134: 119-131.

Chapman, C.A., L.J. Chapman, T.T. Struhsaker, A.E. Zanne, C.J. Clark \& J.R. Poulsen. 2005. A long-term evaluation of fruiting phenology: importance of climate change. J. Trop. Ecol. 21: 31-45.

Chazdon, R.L., S. Careaga, C. Webb \& O. Vargas. 2003. Community and phylogenetic structure of reproductive traits of woody species in wet tropical forests. Ecol. Monogr. 73: 331-348.

Cipollini, M.L. \& D.J. Levey. 1997. Antifungal activity of Solanum fruit glycoalkaloids: Implications for frugivory and seed dispersal. Ecology 78: 799-809.

Corlett, R.T. \& J.V. LaFrankie. 1998. Potential impacts of climate change on tropical Asian forests through an influence on phenology. Climatic Change 39: 439-453.

Cotton, P.A. 2003. Avian migration phenology and global climate change. Proc. Nat. Acad. Sci. USA 100: 12219-12222.

Dalling, J.W., A.S. Davis, B.J. Schutte \& A.E. Arnold. 2010. Seed survival in soil: interacting effects of predation, dormancy and the soil microbial community. J. Ecol. 99:89-95.

Elzinga, J.A., A. Atlan, A. Biere, L. Gigord, A.E. Weis \& G. Bernasconi. 2007. Time after time: flowering phenology and biotic interaction. Trends Ecol. Evol. 22: $432-439$
Eriksson, O. \& J. Ehrlén. 1991. Phenological variation in fruit characteristics in vertebrate-dispersed plants. Oecologia 86: 463-470.

Foster, M.S. 1990. Factors influencing bird foraging preferences among conspecific fruit-trees. Condor 92: 844-854.

Frankie, G.W., H.G. Baker \& P.A. Opler. 1974. Comparative phenological studies of trees in tropical wet and dry forests in lowlands of Costa Rica. J. Ecol. 62: 881-919.

Galetto, L., G. Bernardello, I.C. Isele, J. Vesprini, G. Speroni \& A. Berduc. 2000. Reproductive biology of Erythrina crista-galli (Fabaceae). Ann. Missouri Bot. Gard. 87: 127-145.

Gautier-Hion, A., J.M. Duplantier, R. Quris, F. Feer, C. Sourd, J.P. Decoux, G. Dubost, L. Emmons, C. Erard, P. Hecketsweiler, A. Moungazi, C. Roussilhon \& J.M. Thiollay. 1985. Fruit characters as a basis of fruit choice and seed dispersal in a tropical forest vertebrate community. Oecologia 65: 324-337.

Gentry, A.H. 1974. Coevolutionary patterns in Central American Bignoniaceae. Ann. Missouri Bot. Gard. 61: 728-759.

Gordo, O. \& J.J. Sanz. 2005. Phenology and climate change: a long-term study in a Mediterranean locality. Oecologia 146: 484-495.

Greenberg, R. \& P.P. Marra. (eds.) 2005. Birds of Two Worlds: The Ecology and Evolution of Migration. Johns Hopkins University, Baltimore, Maryland, USA.

Haugaasen, T. \& C.A. Peres. 2005. Tree phenology in adjacent Amazonian flooded and unflooded forests. Biotropica 37: 620-630.

Holbrook, K.M. \& T.B. Smith. 2000. Seed dispersal and movement patterns in two species of Ceratogymna hornbills in a West African tropical lowland forest. Oecologia 125: 249-257.

Holdridge, L.R. 1967. Life Zone Ecology. Tropical Science Center, San José, Costa Rica.

Houle, G. 1995. Seed dispersal and seedling recruitment: the missing link(s). Ecoscience 2: 238-244.

Jordano, P. 1993. Geographical ecology and variation of plant-seed disperser interactions: southern Spanish junipers and frugivorous thrushes. Vegetatio 108: 85-104.

Lechowicz, M.J. 1995. Seasonality of flowering and fruiting in temperate forest trees. Can. J. Bot. 73: 175-182.

Levey, D.J. 1990. Habitat-dependent fruiting behaviour of an understorey tree, Miconia centrodesma, and tropical treefall gaps as keystone habitats for frugivores in Costa Rica. J. Trop. Ecol. 6: 409-420.

Loiselle, B.A. \& J.G. Blake. 1990. Diets of understory fruit-eating birds in Costa Rica: seasonality and resource abundance. Stud. Avian Biol. 13: 91-103. 
Loiselle, B.A. \& J.G. Blake. 1999. Dispersal of Melastome seeds by fruit-eating birds of tropical forest understory. Ecology 80: 330-336.

MacMynowski, D.P. \& T.L. Root. 2007. Climate and the complexity of migratory phenology: sexes, migratory distance, and arrival distributions. Int. J. Biometeorol. 51: 361-373.

Mahoro, S. 2003. Effects of flower and seed predators and pollinators on fruit production in two sequentially flowering congeners. Plant Ecol. 166: 37-48.

Malizia, L.R. 2001. Seasonal fluctuations of birds, fruits, and flowers in a subtropical forest of Argentina. Condor 103: 45-61.

McLaren, K.P. \& M.A. McDonald. 2005. Seasonal patterns of flowering and fruiting in a dry tropical forest in Jamaica. Biotropica 37: 584-590.

Mduma, S.A.R., A.R.E. Sinclair \& R. Turkington. 2007. The role of rainfall and predators in determining synchrony in reproduction of savanna trees in Serengeti National Park, Tanzania. J. Ecol. 95: 184-196.

Milton, K., D.M. Windsor, D.W. Morrison \& M.A. Estribi. 1982. Fruiting phenologies of two Neotropical Ficus species. Ecology 63: 752-762.

Newstrom, L.E., G.W. Frankie \& H.G. Baker. 1991. Survey of long-term flowering patterns in lowland tropical rain forest trees at La Selva, Costa Rica, p. 345-366. In C. Edelin (ed.). L'Arbre, Biologie et Développement, Naturalia Monspeliensia, Montpellier, France.

Newstrom, L.E., G.W. Frankie, H.G. Baker \& R.K. Colwell. 1992. Diversity of long-term flowering patterns at La Selva, p. 142-160. In L.A. McDade, K.S. Bawa, G.S. Hartshorn \& H.A. Hespenheide (eds.). La Selva: Ecology and Natural History of a Neotropical Rain Forest. University of Chicago, Chicago, Illinois, USA.

Newstrom, L.E., G.W. Frankie \& H.G. Baker. 1994. A new classification for plant phenology based on flowering patterns in lowland tropical rain forest trees at $\mathrm{La}$ Selva, Costa Rica. Biotropica 26: 141-159.

Noma, N. \& T. Yumoto. 1997. Fruiting phenology of animal-dispersed plants in response to winter migration of frugivores in a warm temperate forest on Yakushima Island, Japan. Ecol. Res. 12: 119-129.

Poulin, B., S.J. Wright, G. Lefebvre \& O. Calderon. 1999. Interspecific synchrony and asynchrony in the fruiting phenologies of congeneric bird-dispersed plants in Panama. J. Trop. Ecol. 15: 213-227.

Price, M.V. \& N.M. Waser. 1998. Effects of experimental warming on plant reproductive phenology in a subalpine meadow. Ecology 79: 1261-1271.

Rathcke, B. \& E.P. Lacey. 1985. Phenological patterns of terrestrial plants. Annu. Rev. Ecol. Syst. 16: 179-214.

Reich, P.B. 1995. Phenology of tropical forests: patterns, causes, and consequences. Can. J. Bot. 73: 164-174.
Rosselli, L. 1989. El ciclo anual de un ave frugívora migratoria altitudinal, Corapipo leucorrhoa (Pipridae) y los frutos que consume. Tesis de Maestría, Universidad de Costa Rica, San José, Costa Rica.

Sakai, S. 2002. General flowering in lowland mixed dipterocarp forests of South-east Asia. Biol. J. Linnean Soc. 75: 233-247.

Sanford, R.L. Jr., P. Paaby, J.C. Luvall \& E. Phillips. 1994. Climate, geomorphology, and aquatic systems, p. 19-33. In L.A. McDade, K.S. Bawa, H.A. Hespenheide \& G.S. Hartshorn (eds.). La Selva: Ecology and Natural History of a Neotropical Rain Forest. University of Chicago, Chicago, Illinois, USA.

Schleuning, M., N. Bluthgen, M. Florchinger, J. Braun, H.M. Schaefer \& K. Bohning-Gaese. 2011. Specialization and interaction strength in a tropical plantfrugivore network differ among forest strata. Ecology 92: $26-36$.

Sezen, U.U., R.L. Chazdon \& K.E. Holsinger. 2005. Genetic consequences of tropical second-growth forest regeneration. Science 307: 891-891.

Singh, K.P. \& C.P. Kushwaha. 2006. Diversity of flowering and fruiting phenology of trees in a tropical deciduous forest in India. Ann. Bot. 97: 265-276.

Snow, D.W. 1965. A possible selective factor in the evolution of fruiting seasons in a tropical forest. Oikos 15: 274-281.

Stiles, F.G. \& L. Rosselli. 1993. Consumption of fruits of the Melastomataceae by birds: how diffuse is the coevolution? Vegetatio 108: 57-73.

Stiles, F.G. \& A.F. Skutch. 1989. A Field Guide to the Birds of Costa Rica. Cornell University, Ithaca, New York, USA.

Tewksbury, J.J., K.M. Reagan, N.J. Machnicki, T.A. Carlo, D.C. Haak, A.L.C. Penaloza \& D.J. Levey. 2008. Evolutionary ecology of pungency in wild chilies. Proc. Natl. Acad. Sci. USA 105: 11808-11811.

Ting, S., S. Hartley \& K.C. Burns. 2008. Global patterns in fruiting seasons. Glob. Ecol. Biogeogr. 17: 648-657.

van Schaik, C.P., J.W. Terborgh \& S.J. Wright. 1993. The phenology of tropical forests: adaptive significance and consequences for primary consumers. Ann. Rev. Ecol. Syst. 24: 353-377.

Wheelwright, N.T. \& C.H. Janson. 1985. Colors of fruit displays of bird-dispersed plants in two tropical forests. Am. Nat. 126: 777-799.

Wheelwright, N.T. \& G.H. Orians. 1982. Seed dispersal by animals: contrasts with pollen dispersal, problems with terminology, constraints on coevolution. Am. Nat. 119: 402-413.

Zimmerman, J.K., S.J. Wright, O. Calderon, M.A. Pagan \& S. Paton. 2007. Flowering and fruiting phenologies of seasonal and aseasonal neotropical forests: the role of annual changes in irradiance. J. Trop. Ecol. 23: $231-251$. 


\section{APPENDIX I \\ (Available only in the Internet version)}

Phenological patterns of all species in this study that reproduced during 2004. Each figure depicts the proportion of individuals (out of all reproductive individuals by species and site) bearing ripe fruiting (grey bars) or open flowers (black dots). For species represented by $\geq 3$ reproductive individuals growing at more than one elevation, we present the phenological patterns for each species at the landscape level (sites combined). Note that the classification of phenological strategy can depend on the temporal patterns of appearance of new buds or developing fruits which are not depicted here for reasons of visual clarity. 